\title{
Individual Variation in Methionine Sulfoxide-Reducing Activity in Cattle
}

\author{
Takafumi NAGAMINE and Ryoji ONODERA \\ Animal Science Division, Faculty of Agriculture, \\ Miyazaki University, Miyazaki-shi 889-21
}

(Received June 4, 1992)

\begin{abstract}
Key words: methionine sulfoxide, methionine sulfoxide reductase, cattle liver, cattle kidney
\end{abstract}

It is known that methionine is easily converted to methionine sulfoxide (MSO) even in non-enzymatic gentle oxidative conditions ${ }^{6}$. This suggests that methionine present in the livestock feed is oxidized to MSO. In addition, it has been suggested that methionine is converted to MSO in the rumen ${ }^{1,5,7)}$.

In our previous report ${ }^{3)}$, we showed that crude enzyme solutions prepared from the liver and kidney of cattle and swine reduced free MSO to methionine. The MSO-reducing activity was higher in cattle than in swine. However, there were large individual variations within both animal species. Such activities (nmol/h/mg protein, minimum value $\sim$ maximum value) were as follows: cattle liver and kidney, $0.46 \sim 3.74$ and $2.35 \sim 13.43$; swine liver and kidney, $0.31 \sim 2.30$ and $2.04 \sim 5.05$, respectively.

The present paper reports some factors which influence individual variation in MSO-reducing activity in cattle.

\section{Materials and Methods}

Livers and kidneys were obtained from a slaughterhouse in Miyazaki city, Japan. Donor animals (total 37) were classified according to their sex (24 steers and 13 cows), breed (19 Japanese Black, 16 Holstein and 2 Japanese Black and Holstein half-breeds), and age (31 three-year-olds, 1 four-year-old, 4 six-yearolds and 1 unknown). The pathological conditions of the organs were visually judged by the meat inspectors of the slaughterhouse to be normal (27 livers and 33 kianeys) or abnormal (10 livers and 4 kidneys). The abnormalities found in the liver were cavernous capillary ectasis, hepatophyma, nutritional liver necrosis (sawdust liver) or hepatitis. The abnormalities found in the kidney were necrosis or dark-kidney, the pathology common to several diseases. Some data on the raising farms were also collected.

The influences of sex, breed, age, and organ condition on MSO-reducing activity were analyzed statistically by the Student's t test. The influence of the raising farm was examined by analysis of variance with 16 animals from 4 farms. The cattle in each farm were constituted as follows :

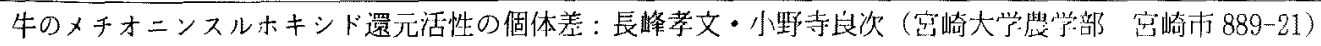




\section{NAGAMINE and ONODERA}

Farm KA. : 3 steers and 1 cow, all Holstein, no abnormalities in liver or kidney

Farm NA. : 2 steers and 2 cows, 3 Japanese Black and 1 half-breed, 1 abnormality for each organ

Farm OH. : all steers, all Holstein, 1 abnormal liver

Farm SA. : 3 steers and $1 \mathrm{cow}$, all Japanese Black, 2 abnormal livers.

All of the cattle were 3 years old.

The assay method used for MSO-reducing activity was the same as that described in our previous report ${ }^{3)}$. The activity was expressed as nmol of methionine produced from MSO per hour per mg protein or $g$ organ.

\section{Results and Discussion}

The correlation of MSO-reducing activity between liver and kidney was calulated in order to examine whethey the cause of differences in individual MSO-reducing activity was the same in both organs or not. The results showed that $\mathrm{MSO}-$ reducing activity closely correlated between the liver and kidney irrespective of whether expressed as $n \mathrm{~mol} / \mathrm{h} / \mathrm{mg}$ protein $(\mathrm{r}=$ $0.6500, p<0.001)$ or $n m o l / h / g$ organ $(r=0.5180$, $\mathrm{p}<0.01)$.

Table 1 shows the influences of sex, breed, age and pathological organ condition on MSOreducing activity. The MSO-reducing activity found in steers was significantly higher than that in cows for both organs. There were no statistical correlations between the activities and breed or age. When the pathological conditions of the organs were analyzed, the normal kidney showed significantly higher activity (nomol/h/mg protein, $\mathrm{p}<0.05 ; \mathrm{nmol} /$ $\mathrm{h} / \mathrm{g}$ organ, $\mathrm{p}<0.01$ ) than the abnormal one, while no difference in activity was found in the liver.

The raising farms were found to affect significantly $(p<0.05)$ the $\mathrm{MSO}$-reducing activity in both organs expressed as $\mathrm{nmol} / \mathrm{h} / \mathrm{mg}$ protein. The MSO-reducing activities (noml/ h/mg protein) of farm KA., NA., OH. and SA. were as follows: liver, $2.84 \pm 0.73,2.19 \pm 0.62$, $1.83 \pm 0.41$ and $1.22 \pm 0.40$; kidney, $12.72 \pm 0.78$, $7.81 \pm 3.89,7.86 \pm 1.56$ and $7.09 \pm 1.06$, respectively. The cattle in each farm constituted both sexes and pathological organ conditions (see Materials and Methods). The significant difference in these farms, therefore, was not caused by the difference in sex on pathological

Table 1. The influences of sex, breed, age and condition of organs on the MSO-reducing activity

\begin{tabular}{|c|c|c|c|c|c|c|c|}
\hline & & & \multirow{3}{*}{ Head } & \multicolumn{4}{|c|}{ MSO-reducing activity } \\
\hline & & & & \multicolumn{2}{|c|}{$(\mathrm{nmol} / \mathrm{mg}$ protein) $\pm \mathrm{SD}$} & \multicolumn{2}{|c|}{$($ nmol/g organ $) \pm S D$} \\
\hline & & & & Liver & Kidney & Liver & Kidney \\
\hline \multirow[t]{2}{*}{ Sex } & \multicolumn{2}{|l|}{ Steer } & 24 & $2.41^{c} \pm 0.80$ & $9.72^{b} \pm 2.34$ & $242^{b} \pm 62$ & $660^{a} \pm 118$ \\
\hline & \multicolumn{2}{|l|}{ Cow } & 13 & $1.75^{c} \pm 0.79$ & $7.12^{b} \pm 2.85$ & $179^{b} \pm 82$ & $451^{a} \pm 192$ \\
\hline \multirow[t]{2}{*}{ Breed } & \multicolumn{2}{|c|}{ Japanese Black } & 19 & $2.36 \pm 0.86$ & $9.48 \pm 2.49$ & $244 \pm 71$ & $633 \pm 136$ \\
\hline & \multicolumn{2}{|c|}{ Holstein } & 16 & $1.97 \pm 0.87$ & $8.11 \pm 3.17$ & $191 \pm 76$ & $539 \pm 218$ \\
\hline \multirow[t]{2}{*}{ Age } & \multicolumn{2}{|c|}{ 3-year-old } & 31 & $2.20 \pm 0.87$ & $9.08 \pm 2.85$ & $224 \pm 75$ & $610 \pm 173$ \\
\hline & \multicolumn{2}{|c|}{4 or 6 -year old } & 5 & $2.03 \pm 0.78$ & $7.05 \pm 1.68$ & $194 \pm 77$ & $433 \pm 128$ \\
\hline \multirow{4}{*}{$\begin{array}{l}\text { Conditions of } \\
\text { organs }\end{array}$} & \multirow[t]{2}{*}{ Liver } & Normal & 27 & $2.23 \pm 0.67$ & & $225 \pm 60$ & \\
\hline & & Abnormal & 10 & $2.07 \pm 1.21$ & & $207 \pm 105$ & \\
\hline & \multirow[t]{2}{*}{ Kidney } & Normal & 32 & & $9.13^{c} \pm 2.64$ & & $613^{6} \pm 160$ \\
\hline & & Abnormal & 4 & & $6.09^{c} \pm 2.89$ & & $369^{b} \pm 184$ \\
\hline
\end{tabular}

${ }_{a}, b c$ : Means with same the superseripts differ significantly ( ${ }^{a} \mathrm{P}<0.001,{ }^{b} \mathrm{P}<0.01,{ }^{c} \mathrm{P}<0.05$ ). 
organ conditions.

These results suggest that the causes of variation in $\mathrm{MSO}-$ reducing activity among the individuals studied here were mainly the differences in sex and raising farm. Since steers and cows are usually fed for fattening and reproduction, respectively, feeding conditions can be different between sexes as well as farms. Feeding conditions influence the predominant species of ruminal microorganisms which may influence the production and degradation of $\mathrm{MSO}$ in the rumen.

The difference in sex influences hormonal conditions. In our previous report ${ }^{4)}$, we suggested that MSO-reducing activity in cattle liver required a methionine sulfoxide reductase and thioredoxin system (thioredoxin, thioredoxin reductase and $\mathrm{NADPH}$ ), which is a hydrogen donor system for ribonucleotide reductase, ornithine decarboxylase, iodothyronine $5^{\prime}$-deiodinase and others. Recently, thioredoxin reductase was shown to be induced by hydrocortisone acetate and glucagon in the rat liver during the perinatal period ${ }^{2)}$. MSOreducing activity is, therefore, influenced by hormones through the thioredoxin system. However, the induction of thioredoxin reductase activity by rat hormones was only 2fold $^{2)}$. On the contrary, the difference in MSO-reducing activity was 8 -fold among the cattle used in the present study. We think that methionine sulfoxide reductase in cattle can be induced by several factors such as MSO concentration in the body and feeds, oxidative conditions in the digestive tract and hormonal condition.

\section{References}

1) Cook, R.M., R.E. Brown and C.L. Davis, Protein metabolism in the rumen: I. Absorption of glycine and other amino acids. J. Dairy Sci., $48:$ 475-483. 1965.

2) Demarquoy, J., A. Fatrand, R. Vaillant and C. Gautier, Development and hormonal control of thioredoxin and thioredoxin-reductase system in the rat liver during the perinatal period. Experientia, 47: 497-500. 1991.

3) Nagamine, T., Y. Horikawa, K. Taket, T. NAGAsawa and R. OnODERA, Apparent characteristics and activity of methionineS-oxide reductase in the liver and kidneys of cattle and swine. Anim. Sci. Technol., 62: 1035-1042. 1991.

4) Nagamine, T., T. Nagasawa and R. OnODERA, Purification of methionine sulfoxide reductase from cattle liver. Anim. Sci. Technol., 63 : 134-140. 1992.

5) OnOdera, R. and K. TAKeI, Methionine sulfoxide in the incubation medium of mixed rumen ciliate protozoa. Agric. Biol. Chem., 50: 767-769. 1989.

6) Patai, S. and C.J.M. Strrling, The chemistry of sulphones and sulphoxides. in Methionine sulfoxide: chemistry and biochemistry. (Brot, N. and H. WeISSBACH, eds.) 851-872. John Wiley and Sons Ltd. 1988.

7) Salsbury, R.L., D.K. Marvil, C.W. Woodmansee and G.F. HaEnlein, Utilization of methionine and methionine hy. droxy analogue by rumen microorganisms in vitro. J. Dairy Sci., $54:$ 390-396. 1971. 